\title{
Geoekološke značajke doline gornjeg toka Une od Martin Broda do Pritoke
}

\begin{abstract}
Alen Lepirica
Gornja dolina Une po svojim specifičnim i atraktivnim prirodnim značajkama već odavno zaslužuje epitet zaštičenog područja. Zbog toga je u posljednje vrijeme pokrenuta procedura proglašenja Nacionalnog parka "Una".

U ovome radu na temelju predhodnih terenskih opservacija i izvršenog geomorfološkog kartiranja provedeno je geoekološko vrednovanje reljefnih oblika metodom indeksa rekreacijskog potencijala. Time je s prostorno-planerskog stanovišta omogućena daljnja valorizacija područja. Istaknute su smjernice buduće namjene prostora NP "Una" (zoniranje, regionalno povezivanje) i prirodne predispozicije za razvoj određenih vidova turizma i rekreacije. Posebno su naglašene neophodne mjere zaštite kojima bi se otklonili sadašnji negativni antropogeni utjecaji u gornjem poriječju Une.

Ključne riječi: Una, geoekološko vrednovanje reljefa, metoda indexa rekreacijskog potencijala, zaštita okoliša, Nacionalni park "Una".

\section{Geoecological Characteristics of the Upper Part of the Una River, From Martin Brod to Pritoka}

The upper part of the Una River Valley has deserved for quite some time a status of a protected area because of its unique and appealing natural characteristics. It is for this reason that a procedure was initiated to nominate the area for the status of the Una National ParkThis text contains a geoecological evaluation of the relief forms, based on the prior field observations and conducted geomorphological mapping, using the recreation potential indexing method. From the environmental planning standpoint, a further valorization of the area has been made possible. The Una National Park area purpose definitions have been emphasized (zoning, regional inter-connection) and natural predispositions for the development of several types of tourist and recreational activities. A special emphasis has been made in reference to the necessary protection measures that would remove the existing negative man-made impact on the upper Una River area.
\end{abstract}

Key words: Una, geoecological evaluation, recreation potential index method, environmental protection, Una National Park.

\section{UVOD}

Istraživanje i vrednovanje - evaluacija reljefa kao jedne od temeljnih datosti prirodnog okoliša (geosfere, ekosfere) se temelji na razrađenim geoekološkim pristupima, ciljevima i zadacima. U ovome radu, geoekološko vrednovanje je usmjereno ka polimorfnom reljefu naglašenog geodiverziteta kao temeljnom fenomenu gornjeg poriječja Une u Bosni 
i Hercegovini. Na sadašnju morfologiju kompozitne i poligenetske gornje doline Une su prvenstveno utjecali tektonski procesi kroz pojave složenih strukturnih formi i raznolika litološka građa terena. Vrednovanje reljefa je provedeno s aspekta turizma odnosno rekreacije u zaštićenom krajoliku (Saletto - Janković, 1995.). Reljef kao i ostale datosti krajolika istraživanog područja obilježavaju minimalni antropogeni utjecaji i okoliš kojeg većim dijelom krasi izvorna priroda. Tako ovaj, ekološki zasad očuvani, krajolik ima sve predispozicije da postane nacionalni park (sl. 1).

S aspekta geoekološkog planiranja (Miklos, 1994.) namjene prostora perspektivnog zaštićenog područja gornje doline Une bi, uz predložene zone sa strogim režimima zaštite, uključivale i šire zone zaštićenog krajolika što otvara mogućnosti razvoja određenih turističko-rekreativnih i sportskih aktivnosti. Upravo na temelju analiziranih geomorfoloških odlika istraživanog područja, odnosno pogodnosti dolinskog krajolika, provedeno je geoekološko vrednovanje reljefa za potrebe turizma, rekreacije i sporta.

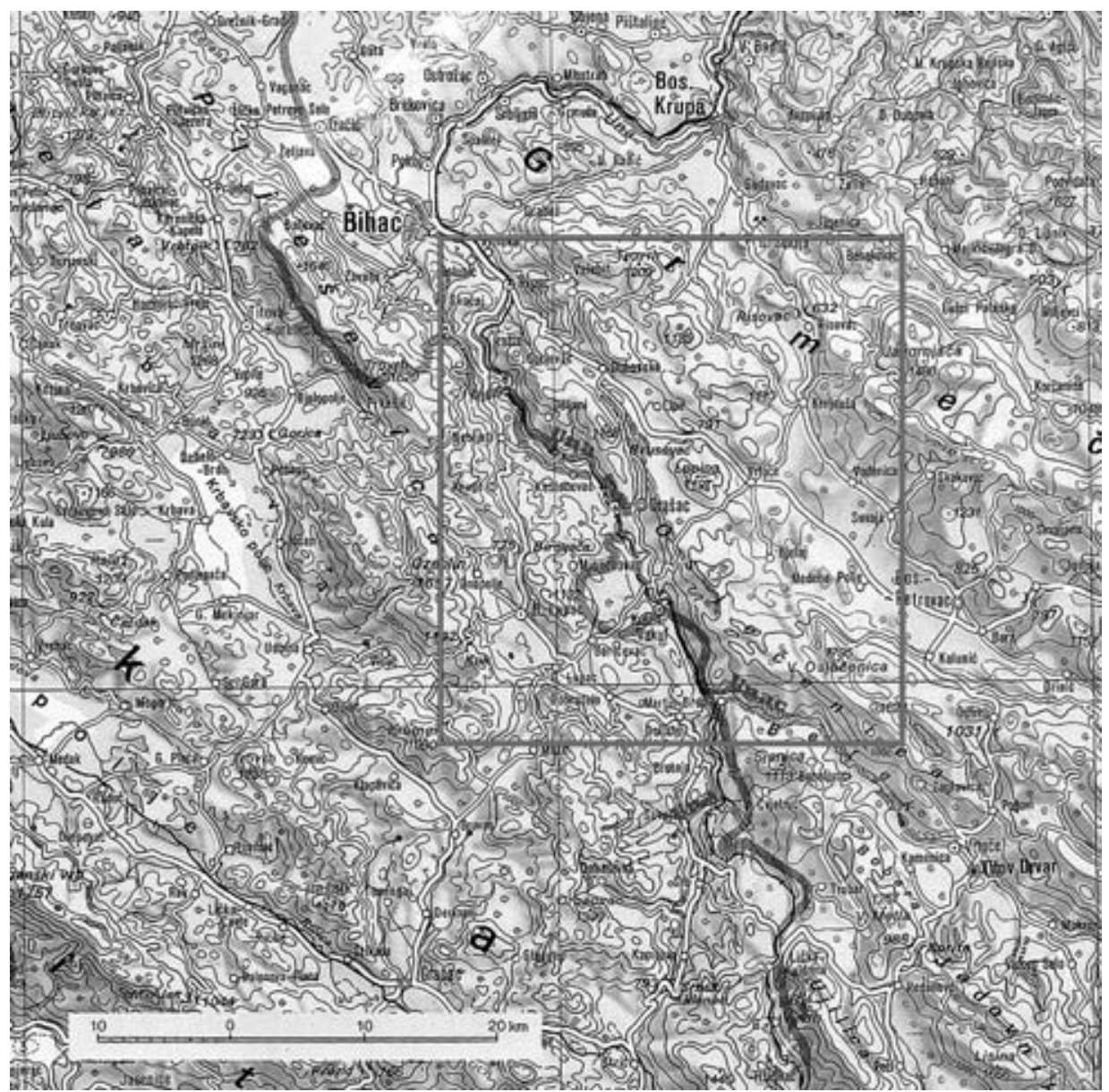

S1. 1. Položaj istraživanog dijela gornjeg poriječja Une

Fig. 1 Study area 
Pri procesu odabira vrsta rekreacije korišten je neformalni pristup temeljen na vlastitom višegodišnjem iskustvu i pretpostavkama koje vrste rekreacije su izvodive na ovome terenu.

Smatramo da su za ovo istraživano područje, kao tipovi rekreacije, najpodesniji: šetnja (rekreativna), planinarenje, rafting, kajakaštvo, kanuing i kanjoning.

Prema navedenim tipovima rekreacije izdvojeno je pet odgovarajućih morfografskih kategorija reljefa za koje je izvršeno geoekološko vrednovanje. To su riječna korita, naplavne ravnice, riječne terase, predgorske stepenice-podovi i padine. Za potrebe raftinga, kanuinga i kajakaštva vrednovana su riječna korita Une, dok je za kanjoning vrednovano korito kanjonske doline Unca. Za potrebe šetnje i rekreativnog planinarenja vrednovane su padine, a naplavne ravnice, riječne terase i predgorske stepenice su namijenjene i vrednovane za potrebe rekreacije.

\section{PRISTUPI VREDNOVANJU}

Pristupi vrednovanja prirodnog krajolika doline Une su izvedeni i djelomično prilagođeni prema razrađenom stupnju pogodnosti reljefa NP "Paklenica" u Republici Hrvatskoj (Saletto - Janković, 1995.) i kanjonu Rakitnice u Bosni i Hercegovini (Lepirica, 2004.). Stupanj pogodnosti reljefa je podrazumijevao sljedeće pokazatelje: fizičku pogodnost, estetsku vrijednost i dostupnost.

Fizička pogodnost reljefa podrazumijeva one reljefne oblike - morfografske kategorije koje su, u ovome slučaju, pogodne za rekreativno planinarenje (šetnju), rafting, kajakaštvo, kanuing i kanjoning. U procesu vrednovanja koji je uključivao bodovanje i kategorizaciju navedenih pet morfografskih kategorija za fizičku pogodnost reljefa su korišteni morfometrijski i morfogenetski podaci (položaj, površina, oblik, izgled, dužina, širina, nagib i mobilnost). Spomenuti podaci su dobiveni na temelju terenskih opservacija, topografskih, morfometrijskih karata te izvršenog geomorfološkog kartiranja istraživanog područja (Spiridonov, 1975., Grupa autora, 1985.). Ograničavajući podaci koji su umanjili potencijalne vrijednosti reljefnih oblika su mobilnost padina odnosno intenzitet i vrsta padinskih procesa. To se posebice odnosi na destruktivne gravitacijske procese odronjavanja, urušavanja i osipanja. Mobilnost padina je vrlo važna s aspekta sigurnosti odnosno potencijalne opasnosti za posjetitelje, posebice za one koji bi prakticirali prolaske kroz fluviokrške kanjonske tjesnace Unca i podnožja okršenih strmaca u sutjeskama Une. Nagibi uzdužnih riječnih profila, geomorfološke i hidrološke karakteristike tokova i riječnih korita su bitno utjecale na određenje njihove namjene i kriterije vrednovanja sa aspekta raftinga, kajakaštva i kanuinga.

Estetska vrijednost odnosno atraktivnost izgleda određenog reljefnog oblika je druga temeljna odrednica pogodnosti reljefa za definirani oblik rekreacije. Reljefni oblici iste morfografske kategorije (npr. riječna korita sa riječnim adama ili bez ada) se mogu razlikovati po svome izgledu a time i po većoj ili manjoj privlačnosti za posjet turista. Stoga je estetska vrijednost vrlo značajna s aspekta vrednovanja reljefa. Određivanje estetske vrijednosti odnosno atraktivnosti je više subjektivne prirode tako da je vrlo teško odabrati realne kriterije za vrednovanje ovoga pokazatelja. 
Dostupnost kao pokazatelj turističke (rekreacijske) vrijednosti prostora uključuje vanjsku i unutarnju dostupnost. Vanjska dostupnost predstavlja udaljenost određenog turističkog (rekreacijskog) područja od područja urbanih zona i značajnijih prometnica. Pored parametra udaljenosti pri vrednovanju vanjske dostupnosti u obzir se uzima kvaliteta prometnica i njihova propusna moć. Unutarnja dostupnost podrazumijeva povezanost unutar turističkog (rekreacijskog) područja. Pri geoekološkoj analizi doline Une vrednovana je samo unutarnja dostupnost čiji su kriteriji prilagođeni zahtjevima navedenih tipova rekreativnih i sportskih aktivnosti izvedena na temelju procjene udaljenosti. ${ }^{1}$ Pri određivanju stupnja dostupnosti također, su vrednovani nagibi i stabilnost padina kojima se pružaju staze. Pri kriterijima vrednovanja su umanjene vrijednosti onih reljefnih oblika usljed nepostojanja staza i njihove relativne nedostupnosti i nepovezanosti unutar promatranog područja.

\section{VREDNOVANJE RELJEFA METODOM INDEKSA REKREACIJSKOG POTENCIJALA}

Pri geoekološkom vrednovanju reljefa doline Une korištena je metoda "indeksa rekreacijskog potencijala" $\left(\mathrm{P}_{\mathrm{R}}\right)$. Prilikom vrednovanja reljefa ove doline navedena metoda je pretrpjela izvjesne promjene u cilju prilagođenja zahtjevima definiranim vidovima rekreacije. $^{2}$ Metoda indeksa rekreacijskog potencijala se temelji na zbrajanju bodova pozitivnog i negativnog predznaka prema čijem se ukupnom zbiru određuje vrijednost bonitetne kategorije vrednovanog reljefnog oblika (Saletto-Janković, 1995.). Bonitetne kategorije reljefa su podijeljene u kategorije od 0 - 9 kategorije tj. prema ukupnom broju bodova kojim je određen stupanj vrijednosti odnosno rekreacijski potencijal vrednovanog reljefnog oblika (tab. 1).

Tab. 1. Bonitetne kategorije reljefa

Tab. 1 Relief quality categories

\begin{tabular}{|c|c|c|}
\hline KAT. & STUPANJ VRIJEDNOSTI RELJEFA & BODOVI \\
\hline 9 & Najvredniji dijelovi reljefa & $91-100$ \\
\hline 8 & Veoma vrijedni dijelovi reljefa & $81-90$ \\
\hline 7 & Pretežito vrijedni dijelovi reljefa & $71-80$ \\
\hline 6 & Relativno vrijedni dijelovi reljefa & $61-70$ \\
\hline 5 & Pretežito manje vrijedni dijelovi reljefa & $51-60$ \\
\hline 4 & Relativno nepogodni dijelovi reljefa & $41-50$ \\
\hline 3 & Pretežito nepogodni dijelovi reljefa & $31-40$ \\
\hline 2 & Nepogodni dijelovi reljefa & $21-30$ \\
\hline 1 & Veoma nepogodni dijelovi reljefa & $11-20$ \\
\hline 0 & Izrazito nepovoljni dijelovi reljefa & $1-10$ \\
\hline
\end{tabular}

Izvor: Saletto-Janković, Geoekološke osobine NP Paklenica, Zagreb, 1995. 
U osnovi ovo je vrlo jednostavna metoda po kojoj svi vrednovani reljefni oblici imaju početnu vrijednost od 100 bodova. Vrednovanje se zapravo temelji na ograničavajućim - korektivnim značajkama reljefa koji utječu na oduzimanje bodova čime se donekle ublažava subjektivan pristup vrednovanju. Geoekološko vrednovanje je provedeno na temelju fizičke pogodnosti, estetske vrijednosti i unutarnje dostupnosti. ${ }^{3}$ Ograničavajući čimbenici kao nedostupnost, mobilnost i nagibi padina, te manji odnosno veći nagibi uzdužnih profila korita, suhoća i ispunjenost stjenskim blokovima, vegetacijski pokrivač i objekti na naplavnim ravnicama, tjemenima riječnih terasa i podova, uz položaj i vizualnu dostupnost su bile korektivne značajke koje ograničavaju ili onemogućuju neku od navedenih rekreacijskih ili sportskih aktivnosti.

Važno je napomenuti da je pri geoekološkom vrednovanju reljefa, korištena ova metoda jer je ona prilagodljiva reljefu gornje doline Une i njezinoj budućoj namjeni u obliku nacionalnog parka. Djelomice izmijenjena metoda indeksa rekreacijskog potencijala je prihvatljiva za vrednovanje turističkih potencijala iako svojim kriterijima umanjuje geoekološku vrijednost određenih reljefnih oblika i nije sasvim prilagodljiva zahtjevima ekstremnih sportova: alpinizma (ne misli se na slobodno penjanje) i kanjoninga.

\section{REZULTATI RADA - PRIRODNE PREDISPOZICIJE ZA RAZVOJ TURIZMA I REKREACIJE}

\section{RIJEČNA KORITA UNE I UNCA}

Nakon provedenog vrednovanja - geoekološke evaluacije je ustanovljeno da riječno korito Une u istraživanom području karakterizira visoka potencijalna turistička vrijednost. To je najvrijednija morfografska kategorija - reljefni oblik ovoga perspektivnog nacionalnog parka.

Korito Une u sutjesci nizvodno od Štrbačkog buka obilježava naglašen nagib uzdužnog profila s pojavama bukova i brzaca . Navedenom metodom je vrednovano visokom 8. bonitetnom kategorijom (veoma vrijedni dijelovi reljefa) što predstavlja veoma dobre prirodne predispozicije za razvoj raftinga i kajakaštva (Weber, 1950.). U sutjesci Une koja počinje od rasjedno predisponiranog Štrbačkog buka, a završava uzvodno od Lohovske kotline (sl. 2, tab. 2, 2a) niski slapovi, bukovi i brzaci u riječnom koritu su rangirani od 1. do 4. stupnja težine za potrebe raftinga. To znači da prevladavaju brzaci i bukovi srednje težine što otvara mogućnosti za masovniju turističku posjetu tijekom ljetnih mjeseci. 


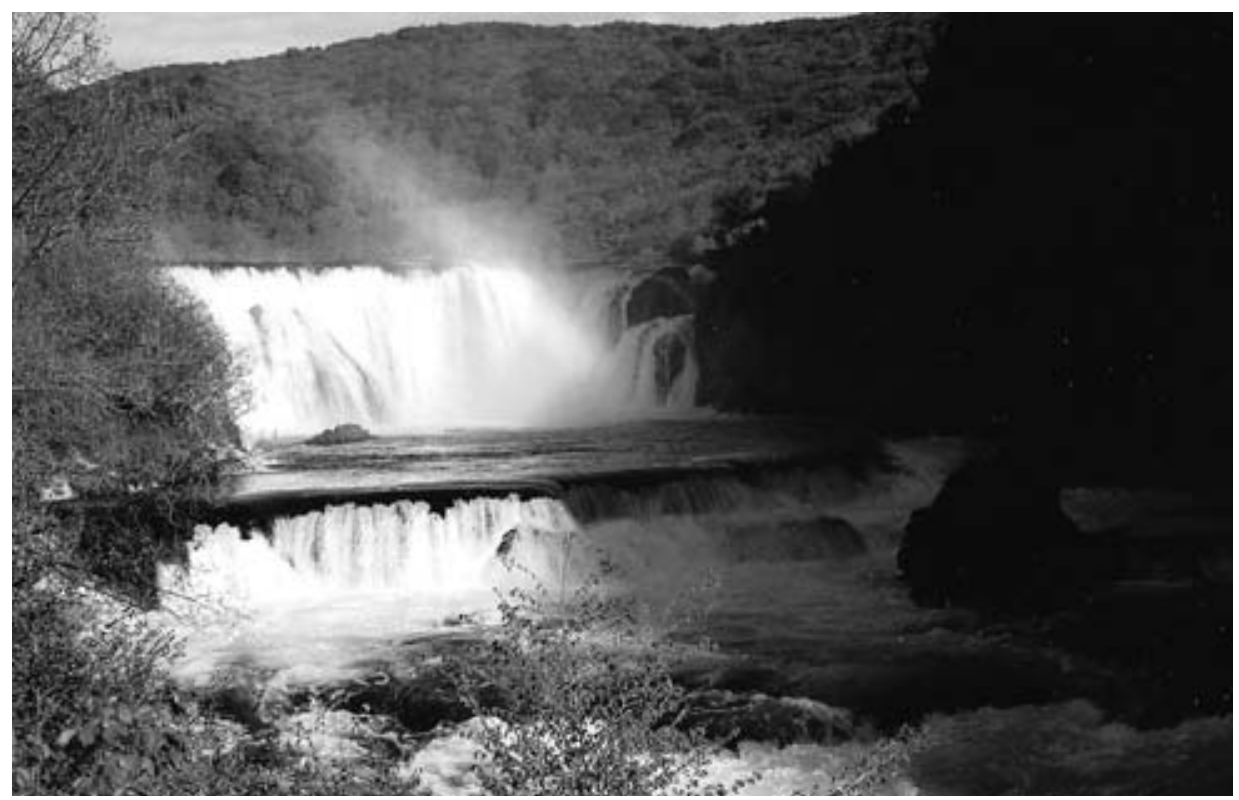

S1. 2. Štrbački buk na rijeci Uni (snimio Alen Lepirica, svibanj 2005.)

Fig. 2 Štrbački buk on the River Una

Tab. 2. Vrednovanje reljefa metodom indeksa rekreacijskog potencijala za potrebe raftinga

Tab.2 Landscape evaluation using recreation potential index for the needs of rafting

\begin{tabular}{|c|c|c|c|c|}
\hline $\begin{array}{l}\text { MORFOGRAF- } \\
\text { SKA } \\
\text { KATEGORIJA }\end{array}$ & $\begin{array}{l}\text { STARTNI } \\
\text { BROJ } \\
\text { BODOVA }\end{array}$ & $\begin{array}{r}\text { BONITETNA } \\
\text { KATEGORIJA }\end{array}$ & KOREKTIVNE ZNAČAJKE & $\begin{array}{l}\text { KORE- } \\
\text { KTIVNI } \\
\text { BODOVI }\end{array}$ \\
\hline $\begin{array}{l}\text { RIJEČNA } \\
\text { KORITA UNE }\end{array}$ & 100 & $9-0$ & $\begin{array}{c}\text { A) DOSTUPNOST: } \\
\text { - staza uz korito }(<1 \mathrm{~h} \text { hoda) } \\
\text { - staza uz korito }(>1 \mathrm{~h} \text { hoda }) \\
\text { - bez staze } \\
\text { B) NAGIBI PADA KORITA (u \%) } \\
0-2 \% \\
2-5 \% \\
5-8 \% \\
8-10 \% \\
>10 \% \\
\text { C) KORITO } \\
\text { - suho }>1 \text { mjesec/god } \\
\text { - s pojavama brzaca i slapova } \\
\text { - ispunjeno stjenskim blokovima } \\
\text { - širina korita }>40 \mathrm{~m} \\
\text { - širina korita }<40 \mathrm{~m} \\
\text { - pojava riječnih ada i sedrenih barijera } \\
\text { D) RAVNOTEŽNO STANJE PADINA } \\
\text { - stabilno } \\
\text { - uvjetno stabilno } \\
\text { - nestabilno }\end{array}$ & $\begin{array}{r}0 \\
-10 \\
-30 \\
\\
\\
-25 \\
0 \\
+10 \\
+5 \\
-10 \\
\\
\\
\\
-10 \\
+10 \\
-20 \\
-10 \\
0 \\
+5 \\
\\
\\
0 \\
-15 \\
-30\end{array}$ \\
\hline
\end{tabular}


Tab. 2a.Vrednovanje riječnog korita Une metodom indeksa rekreacijskog potencijala za potrebe raftinga Tab.2a Evaluation of the Una River bed using recreation potential index for the needs of rafting

\begin{tabular}{|c|c|c|c|c|c|c|c|c|c|c|c|c|}
\hline \multirow[b]{2}{*}{$\begin{array}{l}\text { RIJEČNA KORITA } \\
\text { UNE } \\
\text { UZDUŽNI PROFILI }\end{array}$} & \multirow[b]{2}{*}{ 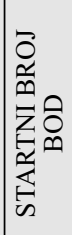 } & \multicolumn{8}{|c|}{ KOREKTIVNE ZNAČAJKE } & \multirow[b]{2}{*}{ 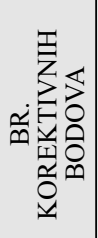 } & \multirow[b]{2}{*}{ 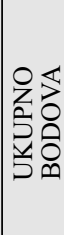 } & \multirow[b]{2}{*}{ 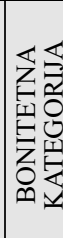 } \\
\hline & & $\begin{array}{l}1 \\
S^{1} \\
5 \\
0 \\
0 \\
0 \\
0 \\
0\end{array}$ & 产 & 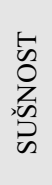 & 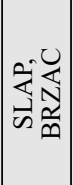 & 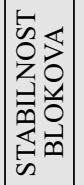 & 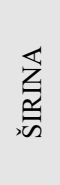 & रींजिं & 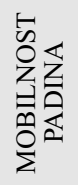 & & & \\
\hline $\begin{array}{l}\text { 1. MARTIN BROD (od } \\
\text { kanjona do ušća Unca) }\end{array}$ & \multicolumn{12}{|c|}{$\begin{array}{l}\text { Dionica nije voziva zbog postojanja više slapova i vodopada visina } \\
\text { preko } 8 \text { metara }\end{array}$} \\
\hline $\begin{array}{l}\text { 2. OD UŠĆA UNCA DO } \\
\text { KULEN VAKUFA }\end{array}$ & 100 & 0 & -25 & 0 & 0 & 0 & -10 & +5 & 0 & -30 & 70 & 6 \\
\hline $\begin{array}{l}\text { 3. OD KULEN } \\
\text { VAKUFA DO KLISE }\end{array}$ & 100 & 0 & -25 & 0 & 0 & 0 & -10 & +5 & 0 & -30 & 70 & 6 \\
\hline $\begin{array}{l}\text { 4.OD KLISE DO KOTE } \\
\text { 292 NIZVODNO OD } \\
\text { ĆELIJA }\end{array}$ & 100 & 0 & -25 & 0 & 0 & 0 & -10 & - & 0 & -35 & 65 & 6 \\
\hline $\begin{array}{l}\text { 5. OD KOTE } 292 \text { DO } \\
\text { MLINA UZVODNO OD } \\
\text { ŠTRBAČKOG BUKA }\end{array}$ & 100 & 0 & -25 & 0 & 0 & 0 & -10 & - & 0 & -35 & 65 & 6 \\
\hline $\begin{array}{l}\text { 6. OD ŠTRBAČKOG } \\
\text { BUKA DO CRNOG } \\
\text { VRELA }\end{array}$ & 100 & 0 & +10 & 0 & +10 & -10 & 0 & +5 & -30 & -15 & 85 & 8 \\
\hline $\begin{array}{l}\text { 7. OD CRNOG VRELA } \\
\text { DO KOTE } 246\end{array}$ & 100 & 0 & +5 & 0 & +10 & -10 & 0 & +5 & -30 & -20 & 80 & 7 \\
\hline $\begin{array}{l}\text { 8. OD KOTE } 246 \text { DO } \\
\text { LOSKUNA }\end{array}$ & 100 & 0 & 0 & 0 & +10 & -10 & 0 & +5 & -30 & -25 & 75 & 7 \\
\hline $\begin{array}{l}\text { 9. OD LOSKUNA DO } \\
\text { RAČIĆA }\end{array}$ & 100 & -10 & -25 & 0 & +10 & 0 & -10 & +5 & 0 & -30 & 70 & 6 \\
\hline $\begin{array}{l}\text { 10. OD RAČIĆA DO } \\
\text { RIPČA }\end{array}$ & 100 & 0 & -25 & 0 & +10 & 0 & -10 & +5 & 0 & -20 & 80 & 7 \\
\hline $\begin{array}{l}\text { 11. OD RIPČA DO } \\
\text { RIBIĆA }\end{array}$ & 100 & 0 & -25 & 0 & +10 & 0 & -10 & +5 & 0 & -20 & 80 & 7 \\
\hline
\end{tabular}

Nešto niže vrijednosti 6. i 7. kategorije, vezano za rafting i kajakaštvo (tab. 3 i 3a), obilježavaju korito Une od Račića do Ribića zbog nagiba korita manjih od $2 \%$ i pojava dugih dionica umirenog riječnog toka. Estetska komponenta bukova i vodopada Troslapa, Dvoslapa, buka pod Bukvom, Ripačkog buka i ostalih nizvodno ka Ribiću uz pojave brojnih riječnih ada i sedrenih barijera je utjecala da korito Une na spomenutom dijelu uzdužnog profila zadrži relativno visoke vrijednosti. 
Tab. 3. Vrednovanje reljefa metodom indeksa rekreacijskog potencijala za potrebe kajakaštva Tab.3 Landscape evaluation using recreation potential index for the needs of kayaking

\begin{tabular}{|c|c|c|c|c|}
\hline $\begin{array}{c}\text { MORFOGRAF- } \\
\text { SKA } \\
\text { KATEGORIJA }\end{array}$ & $\begin{array}{l}\text { STARTNI } \\
\text { BROJ } \\
\text { BODOVA }\end{array}$ & $\begin{array}{l}\text { BONITETNA } \\
\text { KATEGORIJA }\end{array}$ & KOREKTIVNE ZNAČAJKE & $\begin{array}{c}\text { KORE- } \\
\text { KTIVNI } \\
\text { BODOVI }\end{array}$ \\
\hline $\begin{array}{c}\text { RIJEČNA } \\
\text { KORITA UNE }\end{array}$ & 100 & $9-0$ & $\begin{array}{c}\text { A) DOSTUPNOST: } \\
\text { - staza uz korito }(<1 \text { h hoda) } \\
\text { - staza uz korito }(>1 \text { h hoda }) \\
\text { - bez staze } \\
\text { B) NAGIBI PADA KORITA (u \%) } \\
0-2 \% \\
2-5 \% \\
5-8 \% \\
8-10 \% \\
>10 \% \\
\text { C) KORITO } \\
\text { - suho }>1 \text { mjesec/god } \\
\text { - s pojavama brzaca i slapova } \\
\text { - ispunjeno stjenskim blokovima } \\
\text { - širina korita }>40 \mathrm{~m} \\
\text { - širina korita }<40 \mathrm{~m} \\
\text { - pojava riječnih ada i sedrenih } \\
\text { barijera } \\
\text { D) RAVNOTEŽNO STANJE PADINA } \\
\text { - stabilno } \\
\text { - uvjetno stabilno } \\
\text { - nestabilno }\end{array}$ & $\begin{array}{r}0 \\
-10 \\
-30 \\
\\
\\
-25 \\
0 \\
+5 \\
+10 \\
+5 \\
\\
\\
-20 \\
+10 \\
-10 \\
-20 \\
0 \\
+5 \\
\\
\\
0 \\
-15 \\
-30\end{array}$ \\
\hline
\end{tabular}

Riječno korito Une nizvodno od Martin Broda do Štrbačkog buka na dužini od oko $27 \mathrm{~km}$ obilježava mali nagib uzdužnog profila i pojava dugih dionica umirenog toka. Na tom dijelu toka su dva veća buka (nizvodno od Kulena kod mosta za Lapac i uzvodno od Ćelija) i nekoliko manjih bukova i brzaca. Navedena dionica je vrednovana najvišim bonitetnim kategorijama - 8. i 9. za potrebe kanua dvosjeda na što je, uz fizičku pogodnost i estetsku vrijednost riječnog korita, bitno utjecala komponenta dostupnosti zbog postojanja ceste koja većim dijelom povezuje desnu obalu Une (tab. 4 i 4a). 
Tab. 3a.Vrednovanje riječnog korita Une metodom indeksa rekreacijskog potencijala za potrebe kajakaštva Tab.3a Evaluation of the Una River bed using recreation potential index for the needs of kayaking

\begin{tabular}{|c|c|c|c|c|c|c|c|c|c|c|c|c|}
\hline \multirow[b]{2}{*}{$\begin{array}{l}\text { RIJEČNO KORITO } \\
\text { UNE } \\
\text { UZDUŽNI PROFILI }\end{array}$} & \multirow[b]{2}{*}{ 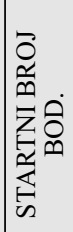 } & \multicolumn{8}{|c|}{ KOREKTIVNE ZNAČAJKE } & \multirow[b]{2}{*}{ 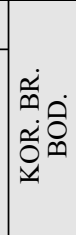 } & \multirow[b]{2}{*}{ 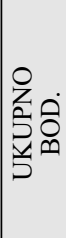 } & \multirow[b]{2}{*}{ 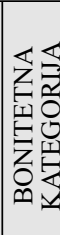 } \\
\hline & & 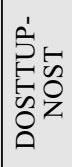 & 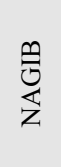 & 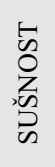 & 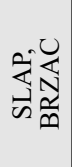 & 的光 & 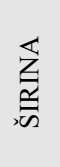 & 幽徖 & 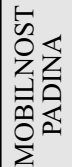 & & & \\
\hline $\begin{array}{l}\text { 1. MARTIN BROD (od } \\
\text { kanjona do ušća Unca) }\end{array}$ & \multicolumn{12}{|c|}{$\begin{array}{c}\text { Dionica nije voziva zbog postojanja više slapova i vodopada visin iznad } 8 \\
\text { metara }\end{array}$} \\
\hline $\begin{array}{l}\text { 2. OD UŠĆCA UNCA DO } \\
\text { KULEN VAKUFA }\end{array}$ & 100 & 0 & -25 & 0 & 0 & 0 & -20 & +5 & 0 & -40 & 60 & 5 \\
\hline $\begin{array}{l}\text { 3. OD KULEN VAKUFA } \\
\text { DO KLISE }\end{array}$ & 100 & 0 & -25 & 0 & 0 & 0 & -20 & +5 & 0 & -40 & 60 & 5 \\
\hline $\begin{array}{l}\text { 4.OD KLISE DO KOTE } 292 \\
\text { NIZVODNO OD ĆELIJA }\end{array}$ & 100 & 0 & -25 & 0 & 0 & 0 & -20 & - & 0 & -45 & 55 & 5 \\
\hline $\begin{array}{l}\text { 5. OD KOTE } 292 \text { DO } \\
\text { MLINA UZVODNO OD } \\
\text { ŚTRBAČKOG BUKA }\end{array}$ & 100 & 0 & -25 & 0 & 0 & 0 & -20 & - & 0 & -45 & 55 & 5 \\
\hline $\begin{array}{l}\text { 6. OD ŠTRBAČKOG BUKA } \\
\text { DO CRNOG VRELA }\end{array}$ & 100 & 0 & +10 & 0 & +10 & -10 & 0 & +5 & -30 & -15 & 85 & 8 \\
\hline $\begin{array}{l}\text { 7. OD CRNOG VRELA DO } \\
\text { KOTE } 246\end{array}$ & 100 & 0 & +10 & 0 & +10 & -10 & 0 & +5 & -30 & -15 & 85 & 8 \\
\hline $\begin{array}{l}\text { 8. OD KOTE } 246 \text { DO } \\
\text { LOSKUNA }\end{array}$ & 100 & -10 & 0 & 0 & +10 & -10 & 0 & +5 & -30 & -35 & 65 & 6 \\
\hline $\begin{array}{l}\text { 9. OD LOSKUNA DO } \\
\text { RAČIĆA }\end{array}$ & 100 & 0 & -25 & 0 & +10 & 0 & -20 & +5 & 0 & -30 & 70 & 6 \\
\hline 10. OD RAČIĆA DO RIPČA & 100 & 0 & -25 & 0 & +10 & 0 & -20 & +5 & 0 & -30 & 70 & 6 \\
\hline 11. OD RIPČA DO RIBIĆA & 100 & 0 & -25 & 0 & +10 & 0 & -20 & +5 & 0 & -30 & 70 & 6 \\
\hline
\end{tabular}

Visoka 8. bonitena kategorija kojom je vrednovano riječno korito za potrebe kanua dvosjeda obilježava uzdužni profil Une na potezu od Loskuna do Ripča zbog izražene fizičke pogodnosti i relativno dobre unutrašnje dostupnosti. Važno je naglasiti da veći dio riječnog toka i korita Une u planiranom zaštićenom području ima povoljne prirodne predispozicije za razvoj kanuinga. Također gornji dio riječnog toka ove tekućice od sutoka sa Krkom do sutjeske uzvodno od Martin Broda (strane korita i obale rijeke prekriva bujna hidrofilna vegetacija vrbe) bi bio pogodan za razvoj kanu safarija. 
Tab. 4. Vrednovanje reljefa metodom indeksa rekreacijskog potencijala za potrebe kanua dvosjeda Tab.4 Landscape evaluation using recreation potential index for the needs of a two-seater canoe

\begin{tabular}{|c|c|c|c|c|}
\hline $\begin{array}{l}\text { MORFOGRAF- } \\
\text { SKA } \\
\text { KATEGORIJA }\end{array}$ & $\begin{array}{l}\text { STARTNI } \\
\text { BROJ } \\
\text { BOD }\end{array}$ & $\begin{array}{l}\text { BONITETNA } \\
\text { KATEGORIJA }\end{array}$ & KOREKTIVNE ZNAČAJKE & $\begin{array}{l}\text { KORE- } \\
\text { KTIVNI } \\
\text { BODOVI }\end{array}$ \\
\hline $\begin{array}{c}\text { RIJEČNA } \\
\text { KORITA UNE }\end{array}$ & 100 & $9-0$ & $\begin{array}{c}\text { A) DOSTUPNOST: } \\
\text { - staza uz korito }(<1 \mathrm{~h} \text { hoda }) \\
\text { - staza uz korito }(>1 \text { h hoda }) \\
\text { - bez staze } \\
\text { B) NAGIBI PADA KORITA (u \%) } \\
0-2 \% \\
2-5 \% \\
5-8 \% \\
8-10 \% \\
>10 \% \\
\text { C) KORITO } \\
\text { - suho }>1 \text { mjesec/god } \\
\text { - s pojavama brzaca i slapova } \\
\text { - ispunjeno stjenskim blokovima } \\
\text { - širina korita }>40 \mathrm{~m} \\
\text { - širina korita }<40 \mathrm{~m} \\
\text { - pojava riječnih ada i sedrenih barijera } \\
\text { D) RAVNOTEŽNO STANJE PADINA } \\
\text { - stabilno } \\
\text { - uvjetno stabilno } \\
\text { - nestabilno }\end{array}$ & $\begin{array}{r}0 \\
-10 \\
-30 \\
\\
0 \\
0 \\
-5 \\
-10 \\
-20 \\
-50 \\
\\
\\
-10 \\
-10 \\
-20 \\
0 \\
-5 \\
-10 \\
\\
0 \\
0 \\
-15 \\
-30\end{array}$ \\
\hline
\end{tabular}

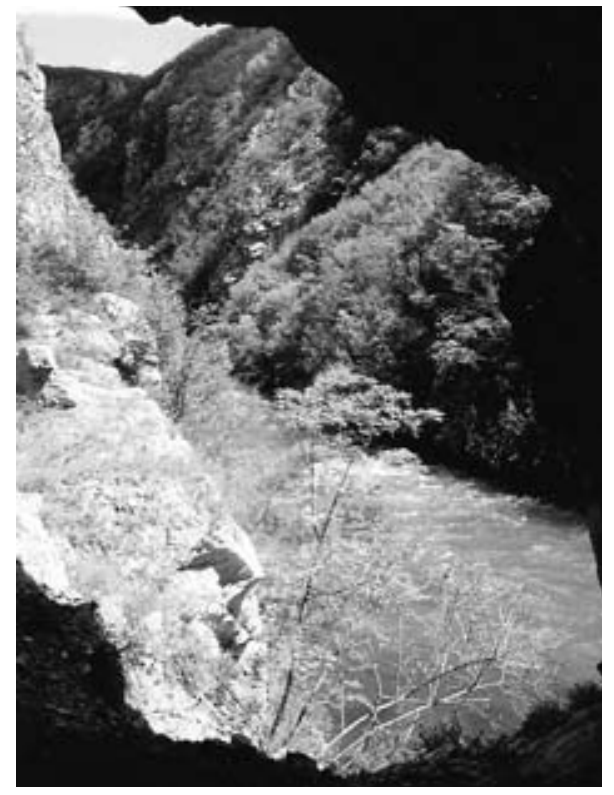

S1. 3. Kanjon Unca (snimio Alen Lepirica, svibanj 2005.) Fig. 3 Canyon of Unac
Riječno korito Une u Martin Brodu nije vrednovano za potrebe raftinga, kajakaštva i kanuinga zbog nagiba uzdužnog profila većeg od $25 \%$ (Grupa autora, 1960). Na ovako izražen nagib su utjecali tektonski prijelomi u koritu izraženi visokim vodopadima i slapovima kao što su Milančev, Veliki i Mali buk, Jalak itd.

Unska sedra je specifična po svom nastanku i razvoju (ookardijska sedra) (Matoničkin, Pavletić, 1963.). Ovdje, njezini brojni i raznovrsni mikroreljefni oblici (sedreni čunjevi, barijerice, brade, zastori i otočići) reljefno izražavaju korito i obale jedinstvenog vodotoka Une. Ostatke sada fosilne sedre ne nalazimo samo na dolinskom dnu (korito i obale) nego i u sastavu niskih riječnih terasa.

Prirodno jedinstvo sedrenih oblika sa slapovima, vodopadima i brzacima daje spe- 
Tab. 4a.Vrednovanje riječnog korita Une metodom indeksa rekreacijskog potencijala za potrebe kanua dvosjeda Tab.4a Evaluation of the Una River bed using recreation potential index for the needs of a two-seater canoe

\begin{tabular}{|c|c|c|c|c|c|c|c|c|c|c|c|c|}
\hline \multirow[b]{2}{*}{$\begin{array}{l}\text { RIJEČNA KORITA } \\
\text { UNE - } \\
\text { UZDUŽNI PROFILI }\end{array}$} & \multirow{2}{*}{ 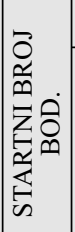 } & \multicolumn{8}{|c|}{ KOREKTIVNE ZNAČAJKE } & \multirow[b]{2}{*}{ 똥ํำ } & \multirow[b]{2}{*}{ 光ô } & \multirow[b]{2}{*}{ 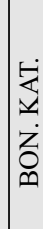 } \\
\hline & & 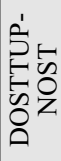 & 远 & $\begin{array}{l}\vec{n} \\
0 \\
\infty \\
\vdots \\
\infty\end{array}$ & 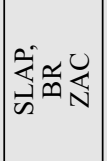 & 战光 & 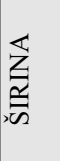 & 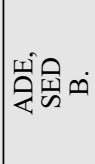 & 帘衣 & & & \\
\hline $\begin{array}{l}\text { 1. MARTIN BROD (od } \\
\text { kanjona do ušća Unca) }\end{array}$ & \multicolumn{12}{|c|}{$\begin{array}{l}\text { Dionica nije voziva zbog postojanja više slapova i vodopada visina } \\
\text { preko } 8 \text { metara }\end{array}$} \\
\hline $\begin{array}{l}\text { 2. OD UŠĆCA UNCA DO } \\
\text { KULEN VAKUFA }\end{array}$ & 100 & 0 & 0 & 0 & 0 & 0 & 0 & -10 & 0 & -10 & 90 & 8 \\
\hline $\begin{array}{l}\text { 3. OD KULEN VAKUFA DO } \\
\text { KLISE }\end{array}$ & 100 & 0 & 0 & 0 & 0 & 0 & 0 & -10 & 0 & -10 & 90 & 8 \\
\hline $\begin{array}{l}\text { 4.OD KLISE DO KOTE } 292 \\
\text { NIZVODNO OD ĆELIJA }\end{array}$ & 100 & 0 & 0 & 0 & 0 & 0 & 0 & - & 0 & 0 & 100 & 9 \\
\hline $\begin{array}{l}\text { 5. OD KOTE 292 DO } \\
\text { MLINA UZVODNO OD } \\
\text { ŚTRBAČKOG BUKA }\end{array}$ & 100 & 0 & 0 & 0 & 0 & 0 & 0 & - & 0 & 0 & 100 & 9 \\
\hline $\begin{array}{l}\text { 6. OD ŠTRBAČKOG BUKA } \\
\text { DO CRNOG VRELA }\end{array}$ & 100 & 0 & -10 & 0 & -10 & -5 & -5 & -10 & -30 & -70 & 30 & 2 \\
\hline $\begin{array}{l}\text { 7. OD CRNOG VRELA DO } \\
\text { KOTE } 246\end{array}$ & 100 & 0 & -20 & 0 & -10 & -5 & -5 & -10 & -30 & -80 & 20 & 1 \\
\hline $\begin{array}{l}\text { 8. OD KOTE } 246 \text { DO } \\
\text { LOSKUNA }\end{array}$ & 100 & -10 & -5 & 0 & -10 & -5 & -5 & -10 & -30 & -75 & 25 & 2 \\
\hline $\begin{array}{l}\text { 9. OD LOSKUNA DO } \\
\text { RAČIĆA }\end{array}$ & 100 & 0 & 0 & 0 & 0 & 0 & 0 & -10 & 0 & -10 & 90 & 8 \\
\hline 10. OD RAČIĆA DO RIPČA & 100 & 0 & 0 & 0 & 0 & 0 & 0 & -10 & 0 & -10 & 90 & 8 \\
\hline 11. OD RIPČA DO RIBIĆA & 100 & 0 & 0 & 0 & -10 & 0 & 0 & -10 & 0 & -20 & 80 & 7 \\
\hline
\end{tabular}

cifično atraktivan ton gornjeunskoj dolini. Pored navedenih estetskih vrijednosti : slapova, vodopada, bukova, brzaca, sedrenih barijera i riječnih ada, svakako treba spomenuti modrozelenu boju vodotoka Une kao posebno vrijednu estetsku komponentu pejsaža ovoga područja.

Na temelju geomorfološko - hidroloških značajki riječno korito Unca u kanjonu je vrednovano za potrebe kanjoninga (tab. 5 i 5a, sl. 3). Osnovni ograničavajući faktor koji je uvelike umanjio vrijednost atraktivnog kanjonskog korita je mobilnost izrazito strmih padina i litica koje obilježavaju intenzivni procesi odronjavanja, urušavanja i osipanja. Tako je ovom metodom riječno korito Unca u gornjem i središnjem sektoru kanjonske doline vrednovano 4 . bonitetnom kategorijom. Na navedenu relativno nisku potencijalnu turističku vrijednost korita je uz izraženu mobilnost padina utjecala nedostupnost $\mathrm{i}$ sušnost korita tijekom ljetnih mjeseci. 6. bonitetnom kategorijom je evaluirano korito Unca u donjem sektoru kanjona, oko i nizvodno od aktivne i stalne hidrogeološke zone Crnog vrela (Milanović,1976.). Ovo izrazito izdašno krško vrelo je nastalo i razvijeno u okršenim gornjokrednim vapnencima s ulošcima dolomita na mjestu transverzalnim rasjedom otkrivene osi sinklinale. Zbog postojanja markirane staze (nizvodno od Crnog vrela) i stalnosti proticaja vodotoka korito s ovog aspekta predstavlja relativno vrijedan dio reljefa (sl. 4). 
Tab. 5. Vrednovanje reljefa metodom indeksa rekreacijskog potencijala za potrebe kanjoniga Tab. 5 Landscape evaluation using recreation potential index for the needs of canyoning

\begin{tabular}{|c|c|c|c|c|}
\hline $\begin{array}{c}\text { MORFOGRAF- } \\
\text { SKA } \\
\text { KATEGORIJA }\end{array}$ & $\begin{array}{l}\text { STARTNI } \\
\text { BROJ } \\
\text { BOD }\end{array}$ & $\begin{array}{l}\text { BONITETNA } \\
\text { KATEGORIJA }\end{array}$ & KOREKTIVNE ZNAČAJKE & $\begin{array}{c}\text { KOR. } \\
\text { BODOVI }\end{array}$ \\
\hline $\begin{array}{c}\text { RIJEČNO } \\
\text { KORITO UNCA }\end{array}$ & 100 & $9-0$ & $\begin{array}{c}\text { A) DOSTUPNOST: } \\
\text { Plan staza - uz korito }(<1 \text { h hoda) } \\
\text { - uz korito ( }>1 \text { h hoda) } \\
\text { Bez staze (kroz korito) } \\
\text { B) NAGIBI PADA KORITA (u) } \\
0-2 \\
3-5 \\
6-12 \\
13-32 \\
\text { C) KORITO } \\
\text { - suho do } 3 \text { mj/god } \\
\text { - suho > } 3 \text { mj/god } \\
\text { - s pojavom slapova i brzaka } \\
\text { D) RAVNOTEŽNO STANJE STRANA } \\
\text { PADINA } \\
\text { - stabilne padine } \\
\text { - moguće spiranje i jaruženje } \\
\text { - moguće osipanje i urušavanje } \\
\text { - akt. spiranje i jaruženje, grohot } \\
\text { - akt. osipanje i povrem. urušavanje } \\
\text { - odroni } \\
\text { - neatraktivan }\end{array}$ & $\begin{array}{r}0 \\
-10 \\
-30 \\
\\
0 \\
+5 \\
+10 \\
+15 \\
\\
\\
-5 \\
-10 \\
+20 \\
\\
\\
0 \\
-5 \\
-10 \\
-25 \\
-35 \\
-50\end{array}$ \\
\hline
\end{tabular}

Tab. 5a.Vrednovanje riječnog korita Unca metodom indeksa rekreacijskog potencijala za potrebe kanjoniga Tab.5a Evaluation of the Unac River bed using recreation potential index for the needs of canyoning

\begin{tabular}{|c|c|c|c|c|c|c|c|c|c|c|}
\hline \multirow[b]{2}{*}{$\begin{array}{l}\text { RIJEČNO KORITO } \\
\text { UNCA - } \\
\text { UZDUŽNI PROFILI }\end{array}$} & \multirow[b]{2}{*}{ 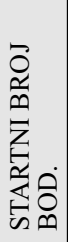 } & \multicolumn{6}{|c|}{ KOREKTIVNE ZNAČAJKE } & \multirow[b]{2}{*}{ 뜽ำ } & \multirow[b]{2}{*}{ نั่ } & \multirow{2}{*}{ 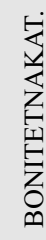 } \\
\hline & & 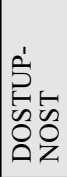 & 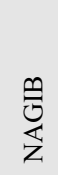 & 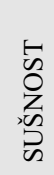 & 岀密芯 & $\stackrel{n}{2} \dot{\Sigma}$ & 꼰고 & & & \\
\hline $\begin{array}{l}\text { 1. DIONICA OD LUKA DO KOTE } 346 \\
\text { (UZVOD NO OD CRNOG VRELA) }\end{array}$ & 100 & -30 & 0 & -5 & +20 & -50 & +10 & -55 & 45 & 4 \\
\hline $\begin{array}{l}\text { 2. OD KOTE } 346 \text { (POD JELIŠAKOM) } \\
\text { DO MARTIN BRODA }\end{array}$ & 100 & -10 & 0 & 0 & +20 & -50 & +10 & -30 & 70 & 6 \\
\hline
\end{tabular}


Geoekološko vrednovanje riječnih korita Une i Unca provedeno metodom indeksa rekreacijskog potencijala se odnosi samo na ljetne mjesece zbog povoljnih hidrometeoroloških uvjeta za navedene sportsko - rekreativne aktivnosti.

\section{NAPLAVNE RAVNICE}

Naplavne ravnice kod Gečeta (Kulen Vakuf) i Otoke kod Gornjeg Lohova su vrednovane najvišom, 9. kategorijom za potrebe rekreacije i turizma prvenstveno zbog dobre povezanosti asfaltnim prometnicama. Nešto nižom 8 . bonitetnom kategorijom su vrednovane spomenute fluvijalne akumulacijske reljefne forme nizvodno od Dvoslapa i uzvodno od Štrbačkog buka. Relativno visoke vrijednosti 7. bonitetne kategorije obilježavaju naplavne ravnice u Palučcima i Rajnovcima na desnoj odnosno Luke na lijevoj obali Une ispod Klise. Preostali oblici naplavnih ravnica izduženih uz tok Une rangirani su kao relativno vrijedni dijelovi reljefa 6. bonitetnom kategorijom (sl. 4 i 5 ). Neke od ovih morfografskih kategorija nisu geoekološki vrednovane zbog miniranosti terena kao što su naplavne ravnice Kaluđerice nizvodno od Kulen Vakufa ili one oko Račića. .

Tab. 6. Vrednovanje reljefa metodom indeksa rekreacijskog potencijala za potrebe rekreacije i turizma Tab.6 Landscape evaluation using recreation potential index for the needs of recreation and tourism

\begin{tabular}{|c|c|c|c|c|}
\hline $\begin{array}{l}\text { MORFOGRAF. } \\
\text { KATEGORIJA }\end{array}$ & $\begin{array}{c}\text { STARTNI } \\
\text { BROJ } \\
\text { BOD }\end{array}$ & $\begin{array}{l}\text { BON. } \\
\text { KAT. }\end{array}$ & KOREKTIVNE ZNAČAJKE & $\begin{array}{c}\text { KOR. } \\
\text { BODOVI }\end{array}$ \\
\hline $\begin{array}{l}\text { NAPLAVNE } \\
\text { RAVNICE }\end{array}$ & 100 & $9-0$ & $\begin{array}{c}\text { A) DOSTUPNOST: } \\
\text { - uz asfaltnu prometmicu } \\
\text { - uz makadamsku prometnicu } \\
\text { - uz pješačku stazu } \\
\\
\text { B) POVRŠINA } \\
->300 \mathrm{~m}^{2} \\
-200-300 \mathrm{~m}^{2} \\
-100-200 \mathrm{~m}^{2} \\
-<100 \mathrm{~m}^{2} \\
\\
\text { C) POKRIVENOST } \\
\text { - bez vegetacije } \\
\text { - djelomice pod vegetacijom } \\
\text { - pod vegetacijom } \\
\text { - pod objektima >40\% površine } \\
\text { - djelomice pod objektima } \\
\text { - bez objekata } \\
\text { D) POLOŽAJ } \\
\text { U neposrednoj blizini } \\
\text { - pojave slapova, brzaka } \\
\text { - pojave riječnih ada } \\
\text { - bez slapova, brzaka } \\
\text { - bez riječnih ada }\end{array}$ & $\begin{array}{r}+5 \\
0 \\
-20 \\
\\
0 \\
-5 \\
-10 \\
-20 \\
\\
+5 \\
-5 \\
-10 \\
-30 \\
-20 \\
0 \\
\\
\\
+10 \\
+5 \\
-20 \\
-10\end{array}$ \\
\hline
\end{tabular}


Tab. 6a.Vrednovanje naplavnih ravnice metodom indeksa rekreacijskog potencijala za potrebe rekreacije $\mathrm{i}$ turizma

Tab.6a Evaluation of the flood plain using recreation potential index for the needs of recreation and tourism

\begin{tabular}{|c|c|c|c|c|c|c|c|c|}
\hline \multirow[b]{2}{*}{ NAPLAVNE RAVNICE } & \multirow[b]{2}{*}{ 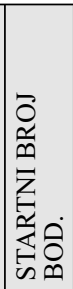 } & \multicolumn{4}{|c|}{$\begin{array}{l}\text { KOREKTIVNE } \\
\text { ZNAČAJKE }\end{array}$} & \multirow[b]{2}{*}{ ํํำ } & \multirow[b]{2}{*}{ ن் } & \multirow[b]{2}{*}{ 宽安 } \\
\hline & & 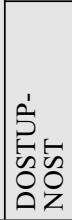 & 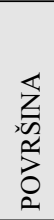 & $\begin{array}{l}\text { 勿 } \\
0 \\
z \\
z \\
z \\
z \\
0 \\
0 \\
0\end{array}$ & 离崖 & & & \\
\hline $\begin{array}{l}\text { 1. MARTIN BROD - UZVODNO ZAVRŠETAK } \\
\text { KLISURE UNE }\end{array}$ & 100 & 0 & -20 & +5 & -15 & -30 & 70 & 6 \\
\hline 2. NIZVODNO OD UŠĆA UNCA & 100 & 0 & -10 & -5 & -15 & -30 & 70 & 6 \\
\hline $\begin{array}{l}\text { 3. SELIŠTE } \\
\text { (LIJEVA OBALA) }\end{array}$ & 100 & -20 & 0 & -5 & -15 & -40 & 60 & 5 \\
\hline 4. PALUČCI & 100 & 0 & -5 & -5 & -15 & -25 & 75 & 7 \\
\hline $\begin{array}{l}\text { 5. KULEN VAKUF } \\
\text { GEČET }\end{array}$ & 100 & +5 & -5 & -5 & 0 & -5 & 95 & 9 \\
\hline $\begin{array}{l}\text { 6. NIZVODNO } 400 \text { METARA OD MOSTA ZA } \\
\text { LAPAC, LIJEVA OBALA }\end{array}$ & 100 & 0 & -10 & -5 & -15 & -30 & 70 & 6 \\
\hline 7. POD RAJNOVCIMA & 100 & +5 & -10 & -5 & -15 & -25 & 75 & 7 \\
\hline $\begin{array}{l}\text { 8. LUKE (KLISA) } \\
\text { LIJEVA OBALA }\end{array}$ & 100 & 0 & 0 & +5 & -30 & -25 & 75 & 7 \\
\hline 9. ĆELIJE & 100 & 0 & -5 & -5 & -30 & -40 & 60 & 5 \\
\hline 10. UZVODNO OD ŠTRBAČKOG BUKA & 100 & 0 & -20 & +5 & 0 & -15 & 85 & 8 \\
\hline 11. UZVODNO OD TROSLAPA (LIJEVA OBALA) & 100 & 0 & -20 & -10 & 0 & -30 & 70 & 6 \\
\hline 12. DVOSLAP (LIJEVA OBALA) & 100 & 0 & -20 & -10 & +15 & -15 & 85 & 8 \\
\hline 13. OTOKA (G. LOHOVO) LIJEVA OBALA & 100 & +5 & 0 & -25 & +15 & -5 & 95 & 9 \\
\hline
\end{tabular}

\section{RIJEČNE TERASE}

Iznad dolinskog dna, u kotlinskim proširenjima Kulen Vakufa, Klise, Lohova te Martinbrodskoj i Bihaćkoj zavali nalazimo reljefne oblike riječnih terasa. Najvišom 9. kategorijom su vrednovani terasni nivoi Martin Broda zbog neposredne blizine vodopada, sedrenih barijera, riječnih ada te prometne povezanosti asfaltnom cestom. Riječne terase iznad Unca u Martin Brodu i iznad Une na lijevoj dolinskoj strani kod mosta za Lapac nizvodno od Kulen Vakufa su vrednovane kao veoma vrijedni dijelovi reljefa (8. bonitetna kategorija) namijenjene potrebama rekreacije i turizma (tab.7 i 7a, sl. 4) Nakon provedenog vrednovanja isti broj bodova je dobila i niska riječna terasa Ždralinaca nizvodno od Ripča. Nešto nižom vrijednosti 6 . bonitetne kategorije vrednovnai su fragmenti terasa $u$ Palučcima. Niskom 3. kategorijom kao pretežno nepogodan dio reljefa je vrednovana terasa Klise na čijem su tjemenu izgrađeni objekti i bliski umireni tok Une bez atraktivnih slapova, brzaca i sedrenih barijera. 
Alen Lepirica - Geoekološke značajke doline gornjeg toka Une od Martin Broda do Pritoke

Tab. 7 Vrednovanje reljefa metodom indeksa rekreacijskog potencijala za potrebe rekreacije i turizma Tab.7. Landscape evaluation using recreation potential index for the needs of recreation and tourism

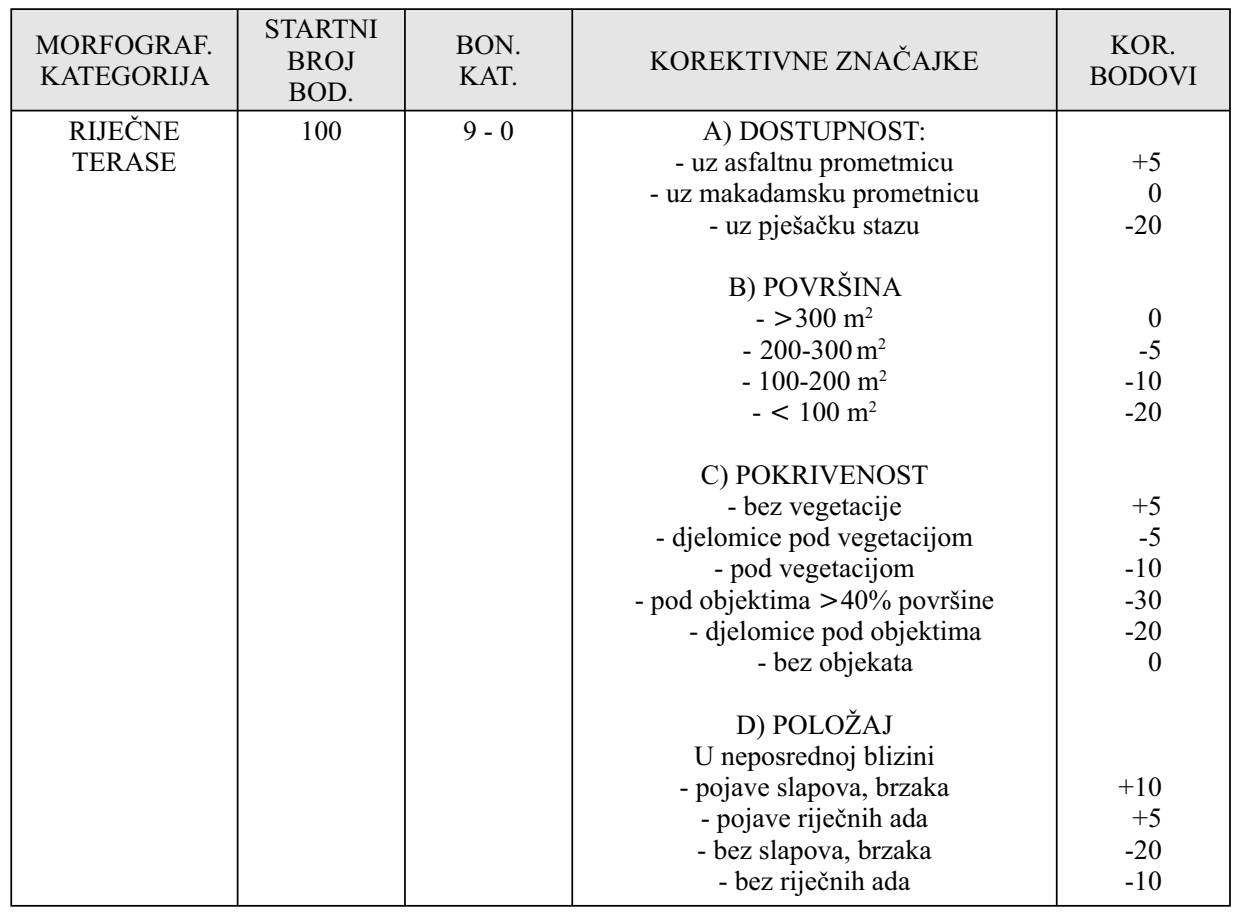

Tab. 7a. Vrednovanje riječnih terasa metodom indeksa rekreacijskog potencijala za potrebe rekreacije i turizma Tab.7a Evaluation of the river terraces using recreation potential index for the needs of recreation and tourism

\begin{tabular}{|c|c|c|c|c|c|c|c|c|}
\hline \multirow[b]{2}{*}{ RIJEČNE TERASE } & \multirow[b]{2}{*}{ 矛官 } & \multicolumn{4}{|c|}{ KOREKTIVNE ZNAČAJKE } & \multirow[b]{2}{*}{ 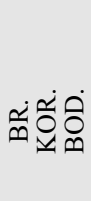 } & \multirow[b]{2}{*}{ ப் } & \multirow[b]{2}{*}{ 忘㐫 } \\
\hline & & 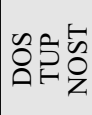 & 占厽 & 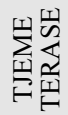 & 究文罗 & & & \\
\hline $\begin{array}{l}\text { 1. MARTIN BROD } \\
\text { IZNAD UNE }\end{array}$ & 100 & +5 & 0 & -25 & +15 & -5 & 95 & 9 \\
\hline $\begin{array}{l}\text { 2. MARTIN BROD } \\
\text { IZNAD UNCA }\end{array}$ & 100 & +5 & -5 & -25 & +10 & -15 & 85 & 8 \\
\hline 3. PALUČCI & 100 & 0 & -10 & -25 & +5 & -30 & 70 & 6 \\
\hline $\begin{array}{l}\text { 4. MOST ZA LAPAC } \\
\text { (LIJEVA STRANA) }\end{array}$ & 100 & 0 & -20 & +5 & 0 & -15 & 85 & 8 \\
\hline 5. KLISA & 100 & 0 & -5 & -30 & -30 & -65 & 35 & 3 \\
\hline 6. ŽDRALINCI & 100 & -20 & 0 & -5 & +10 & -15 & 85 & 8 \\
\hline
\end{tabular}




\section{PREDGORSKE STEPENICE}

Pedimenti ili predgorske stepenice vrednovane navedenom metodom za potrebe rekreacije i turizma u ovom području pokazali su manju potencijalnu turističku vrijednost u odnosu na spomenute reljefne oblike. Najvećom 7. bonitetnom kategorijom vrednovani su relativno dostupni, blago nagnuti, prisojno orijentirani pedimenti Kliševića i Tavana na desnoj dolinskoj strani nizvodno od Kulen-Vakufa (tab 8 i 8a, sl. 4).

Predgorska stepenica Ostrovice, relativno dostupna (makadamska prometnica), s izvanrednim vidicima ka rijeci Uni, dolinskom dnu, padinama i okolnim uzvišenjima je vrednovana 6. bonitetnom kategorijom. Ostale vrednovane predgorske stepenice, kao što su Grabež iznad Lohova na lijevoj odnosno Bosanski Doljani (Stuparuše, Donje selo) na desnoj dolinskoj strani, su vrednovane 4. i 5. kategorijom uglavnom zbog vegetacijskog pokrivača i vizualne nedostupnosti atraktivnog korita Une.

Tab. 8. Vrednovanje reljefa metodom indeksa rekreacijskog potencijala za potrebe rekreacije i turizma Tab.8 Landscape evaluation using recreation potential index for the needs of recreation and tourism

\begin{tabular}{|c|c|c|c|c|}
\hline $\begin{array}{l}\text { MORFOGRAF. } \\
\text { KATEGORIJA }\end{array}$ & $\begin{array}{l}\text { STARTNI } \\
\text { BROJ } \\
\text { BOD }\end{array}$ & $\begin{array}{l}\text { BON. } \\
\text { KAT. }\end{array}$ & KOREKTIVNE ZNAČAJKE & $\begin{array}{l}\text { KOR. } \\
\text { BODOVI }\end{array}$ \\
\hline $\begin{array}{l}\text { PREDGORSKE } \\
\text { STEPENICE }\end{array}$ & 100 & $9-0$ & $\begin{array}{c}\text { A) DOSTUPNOST: } \\
\text { - uz asfaltnu prometnicu } \\
\text { - uz makadamsku prometnicu } \\
\text { - uz pješačku stazu } \\
\text { B) POVRŠINA }\left(\mathrm{u} \mathrm{km}^{2}\right) \text { : } \\
->2 \mathrm{~km}^{2} \\
-1-2 \mathrm{~km}^{2} \\
-0,5-1 \mathrm{~km}^{2} \\
-<0,5 \mathrm{~km}^{2} \\
\left.\text { C) NAGIB (u }{ }^{\circ}\right) \text { : } \\
-0-2 \\
-3-5 \\
-6-12 \\
\text { D) POKRIVENOST: } \\
\text { - pod objektima }>20 \% \text { površine poda } \\
\text { - bez objekata } \\
\text { - djelomice pod vegetacijom } \\
\text { - prekriven vegetacijom } \\
\text { - bez vegetacije } \\
\text { E) VIZUALNA DOSTUPNOST: } \\
\text { Dolinsko dno s riječnim koritom } \\
\text { - vidljivo } \\
\text { - nevidljivo }\end{array}$ & $\begin{array}{r}0 \\
-10 \\
-20 \\
\\
+5 \\
0 \\
-5 \\
-15 \\
\\
0 \\
-5 \\
-15 \\
\\
\\
-20 \\
0 \\
0 \\
-10 \\
-10 \\
\\
\\
+5 \\
-20\end{array}$ \\
\hline
\end{tabular}


Tab. 8a.Vrednovanje predgorskih stepenica-podova metodom indeksa rekreacijskog potencijala za potrebe rekreacije i turizma

Tab.8a Evaluation of the foreland steps using recreation potential index for the needs of recreation and tourism

\begin{tabular}{|c|c|c|c|c|c|c|c|c|c|}
\hline \multirow[b]{2}{*}{$\begin{array}{l}\text { PREDGORSKE } \\
\text { STEPENICE }\end{array}$} & \multirow{2}{*}{ 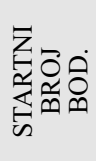 } & \multicolumn{5}{|c|}{ KOREKTIVNE ZNAČAJKE } & \multirow[b]{2}{*}{ 욤ㅇำ } & \multirow[b]{2}{*}{ ㅂㅇㅇ } & \multirow{2}{*}{$\begin{array}{l}\dot{\Xi} \\
\underline{1} \\
\dot{z} \\
0\end{array}$} \\
\hline & & $\begin{array}{l}n \\
0 \\
0 \\
0\end{array}$ & 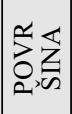 & 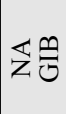 & 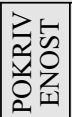 & 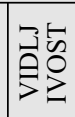 & & & \\
\hline 1. OSTROVICA & 100 & -10 & -5 & -15 & -10 & +5 & -35 & 65 & 6 \\
\hline 2. DEMIROVIĆA BRDO & 100 & -20 & -5 & -5 & -20 & +5 & -45 & 55 & 5 \\
\hline 3. KLIŠEVIĆ & 100 & -10 & -5 & -15 & 0 & +5 & -25 & 75 & 7 \\
\hline 4. STUPARUŠE - CRKVINE & 100 & -20 & +5 & -5 & -10 & -20 & -50 & 50 & 4 \\
\hline 5. DONJE SELO & 100 & -20 & 0 & -5 & -10 & -20 & -55 & 45 & 4 \\
\hline 6. JUGOISTOČNO OD KRAKOVA & 100 & -10 & -5 & -5 & -10 & +5 & -25 & 75 & 7 \\
\hline 7. TAVANI & 100 & -10 & -5 & -5 & -10 & +5 & -25 & 75 & 7 \\
\hline 8. GRABEŽ IZNAD LOHOVA & 100 & -20 & +5 & 0 & -10 & -20 & -45 & 55 & 5 \\
\hline
\end{tabular}

\section{PADINE}

Dinamični neotektonski procesi, heterogen litološki sastav te aktivno djelovanje egzogeomorfoloških činilaca su bitno utjecali na složen morfološki izgled kompozitnih dolina Une i Unca. Zbog toga su se ovdje formirale padine raznolike po svom obliku kao što su: konveksne i konkavne padine, strmci i složeni padinski oblici (Bognar, 1987). Tako je pri geoekološkom vrednovanju padinskih strana za potrebe šetnje i planinarenja dobiven veoma širok raspon bonitetnih kategorija od 0 . do najviše 9. kategorije (tab. 9a i 9).

Tab. 9. Vrednovanje reljefa metodom indeksa rekreacijskog potencijala za potrebe šetnje i planinarenja Tab. 9 Landscape evaluation using recreation potential index for the needs of promenade and mountaineering

\begin{tabular}{|c|c|c|c|c|}
\hline $\begin{array}{l}\text { MORFOGRAF. } \\
\text { KATEGORIJA }\end{array}$ & $\begin{array}{c}\text { START } \\
\text { BROJ } \\
\text { BOD } \\
\end{array}$ & $\begin{array}{l}\text { BON. } \\
\text { KAT. }\end{array}$ & KOREKTIVNE ZNAČAJKE & $\begin{array}{c}\text { KOR. } \\
\text { BODOVI }\end{array}$ \\
\hline PADINE & 100 & $9-0$ & $\begin{array}{c}\text { A) NAGIB PADINA } \\
0^{\circ}-2^{\circ} \\
3^{\circ}-5^{\circ} \\
6^{\circ}-12^{\circ} \\
13^{\circ}-32^{\circ} \\
33^{\circ}-55^{\circ} \\
>55^{\circ} \\
\text { B) RAVNOTEŽNO STANJE STRANA PADINA } \\
\text { - stabilne padine } \\
\text { - moguće spiranje i jaruženje } \\
\text { - moguće osipanje i urušavanje } \\
\text { - akt. spiranje i jaruženje, grohot } \\
\text { - akt. osipanje i povrem. urušavanje } \\
\text { - odroni } \\
\text { C) DOSTUPNOST } \\
\text { - sa stazom } \\
\text { - bez staze }\end{array}$ & $\begin{array}{r}0 \\
-5 \\
-10 \\
-25 \\
-35 \\
-40 \\
\\
\\
0 \\
-10\end{array}$ \\
\hline
\end{tabular}


Tab. 9a. Vrednovanje padina metodom indeksa rekreacijskog potencijala za potrebe šetnje i planinarenja Tab.9a Evaluation of slopes using recreation potential index for the needs of promenade and mountaineering

\begin{tabular}{|c|c|c|c|c|c|c|c|}
\hline \multirow[b]{2}{*}{ PADINE } & \multirow[b]{2}{*}{ 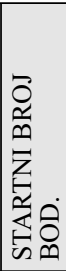 } & \multicolumn{3}{|c|}{$\begin{array}{l}\text { KOREKTIVNE } \\
\text { ZNACAJKE }\end{array}$} & \multirow[b]{2}{*}{ 㫕。 } & \multirow[b]{2}{*}{ 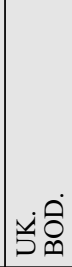 } & \multirow[b]{2}{*}{ 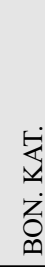 } \\
\hline & & 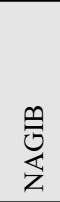 & 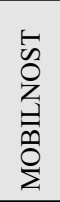 & $\begin{array}{l}\text { 勿 } \\
0 \\
z \\
\vdots \\
\vdots \\
0 \\
0 \\
0\end{array}$ & & & \\
\hline $\begin{array}{l}\text { 1. KANJON UNCA (OD MLINARSKE STRANE DO } \\
\text { POD JELIŠAKOM) }\end{array}$ & 100 & -49 & -40 & -10 & -99 & 1 & 0 \\
\hline $\begin{array}{l}\text { 2. KANJON UNCA (DONJI SEKTOR KANJONA OKO } \\
\text { CRNOG VRELA) }\end{array}$ & 100 & -49 & -35 & 0 & -84 & 16 & 1 \\
\hline $\begin{array}{l}\text { 3. PADINA ISTOČNO OD MARTIN BRODA ISPOD } \\
\text { ĆELIJE TT. } 671\end{array}$ & 100 & -29 & -10 & 0 & -39 & 61 & 6 \\
\hline $\begin{array}{l}\text { 4. PADINA POD VRŠINAMA (LIJEVA DOLINSKA } \\
\text { STRANA IZNAD ŽELJ. ST. MARTIN BROD) }\end{array}$ & 100 & -29 & -10 & 0 & -39 & 61 & 6 \\
\hline $\begin{array}{l}\text { 5. PADINA IZNAD KULEN VAKUFA ISPOD } \\
\text { OSTROVICE }\end{array}$ & 100 & -29 & -5 & 0 & -34 & 66 & 6 \\
\hline 6. PADINE NA POTEZU: KALATI - KLISA - LUKE & 100 & -4 & 0 & 0 & -4 & 96 & 9 \\
\hline 7. RAJNOVCI & 100 & -14 & -5 & 0 & -19 & 81 & 8 \\
\hline 8. DOLJANI - LUKE & 100 & -14 & -5 & 0 & -19 & 81 & 8 \\
\hline 9. KLIŠEVIĆ - LUKE & 100 & -14 & -5 & 0 & -19 & 81 & 8 \\
\hline 10. LJUTOČ (ZAPADNA PADINA) & 100 & -29 & -25 & 0 & -54 & 46 & 4 \\
\hline 11. STRANA ISTOČNO IZNAD ORAŠCA & 100 & -29 & -25 & 0 & -54 & 46 & 4 \\
\hline $\begin{array}{l}\text { 12. KLISURA UNE (OD ŠTRBAČKOG BUKA DO } \\
\text { CRNOG VRELA) }\end{array}$ & 100 & -29 & -25 & 0 & -54 & 46 & 4 \\
\hline 13. PADINE OD CRNOG VRELA DO RUDENJKA & 100 & -29 & -25 & 0 & -54 & 46 & 4 \\
\hline $\begin{array}{l}\text { 14. PADINE POD LOSKUNSKIM KAMENOM } \\
\text { (LIJEVA DOL. STR.) }\end{array}$ & 100 & -39 & -40 & -10 & -89 & 11 & 1 \\
\hline 15. DOLJANI & 100 & -14 & -5 & 0 & -19 & 81 & 8 \\
\hline 16. KRAKOVO & 100 & -14 & 0 & 0 & -14 & 86 & 8 \\
\hline 17. MALI LJUTOČ - DULIBA & 100 & -29 & -25 & 0 & -54 & 46 & 4 \\
\hline 18. MALI LJUTOČ - MALI RAČIĆ & 100 & -29 & -25 & 0 & -54 & 46 & 4 \\
\hline
\end{tabular}

Najvišom 9. kategorijom je vrednovana blaga padinska kosa na potezu Kalati - Klisa zbog stabilnosti i postojanja staza. Visokom 8. kategorijom za potrebe šetnje i planinarenja su geoekološki vrednovane padine umjerenijih nagiba u Rajnovcima, Bosanskim Doljanima, Krakovu i na potezima Klišević - Luke i Bosanski Doljani - Luke. Nešto nižom 6. kategorijom, zbog naglašenijih nagiba, vrednovane su padine Ostrovice te padine istočno i zapadno od Martin Broda. 4. bonitetna kategorija obilježava padinske plohe izraženije mobilnosti sa čestim pojavama točila i siparišnih zastora. To su: zapadna padina Ljutoča, Strana istočno od Orašca, padine u sutjesci Une kuda se proteže staza na potezu Štrbački buk - Crno vrelo - Rudenjak te padine na potezu Mali Račić - Mali Ljutoč - Duliba. 
Najniže potencijalne turističke vrijednosti dobivene ovom metodom obilježavaju izuzetno mobilne, mikrotektonski ispucale strmce i litice (odronjavanje i urušavanje) kanjona Unca i sutjeske Une pod Loskunskim kamenom.

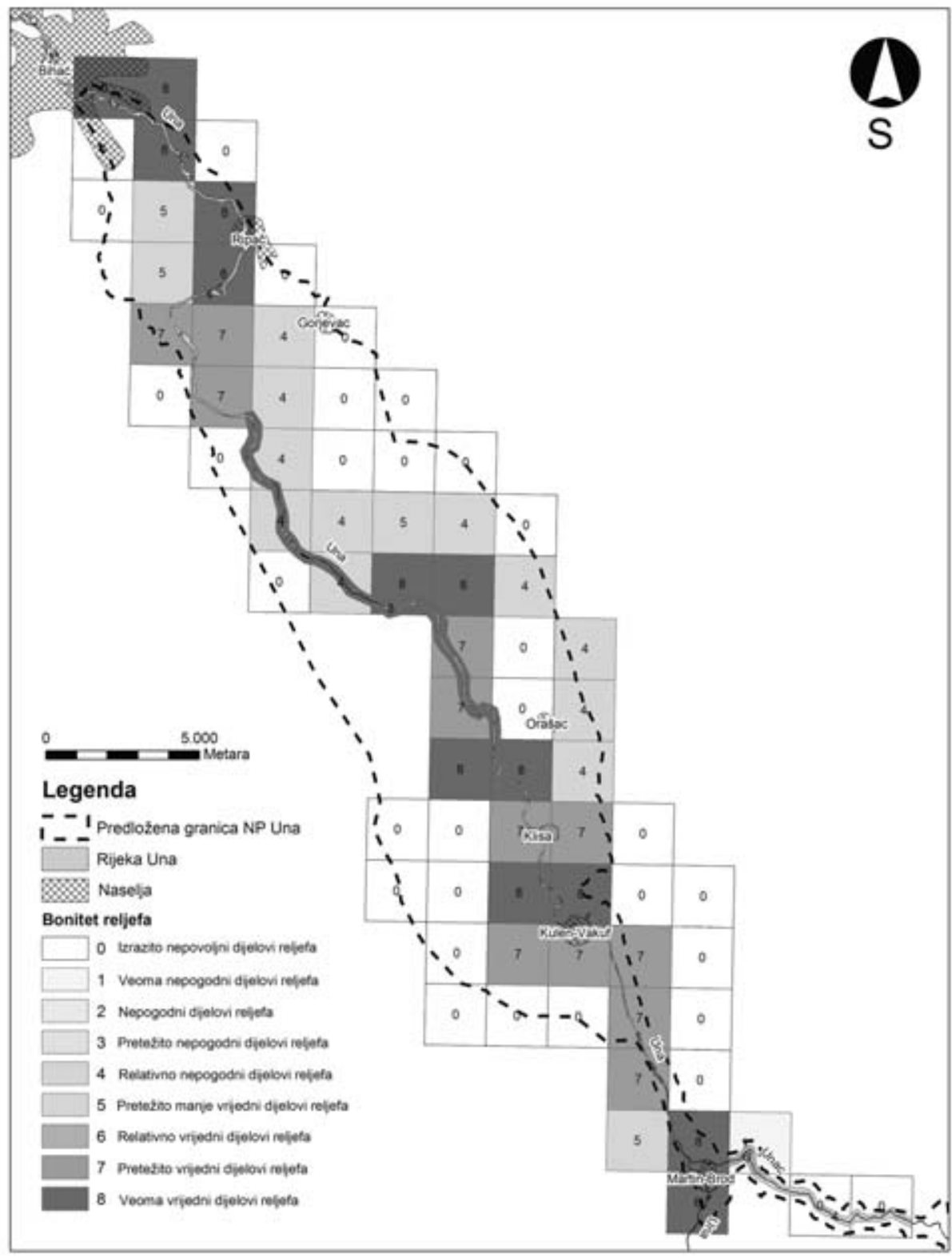

S1. 4. Karta bonitetnih kategorija reljefa budućeg NP,Una”. Predložena granica NP predložena je na temelju prirodnih i antropogeografskih obilježja istraživanog područja.

Fig. 4 Map of the relief quality categories of the future National Park Una. The proposed limits of the National Park have been based on natural and anthropo-geographic properties of the study area 


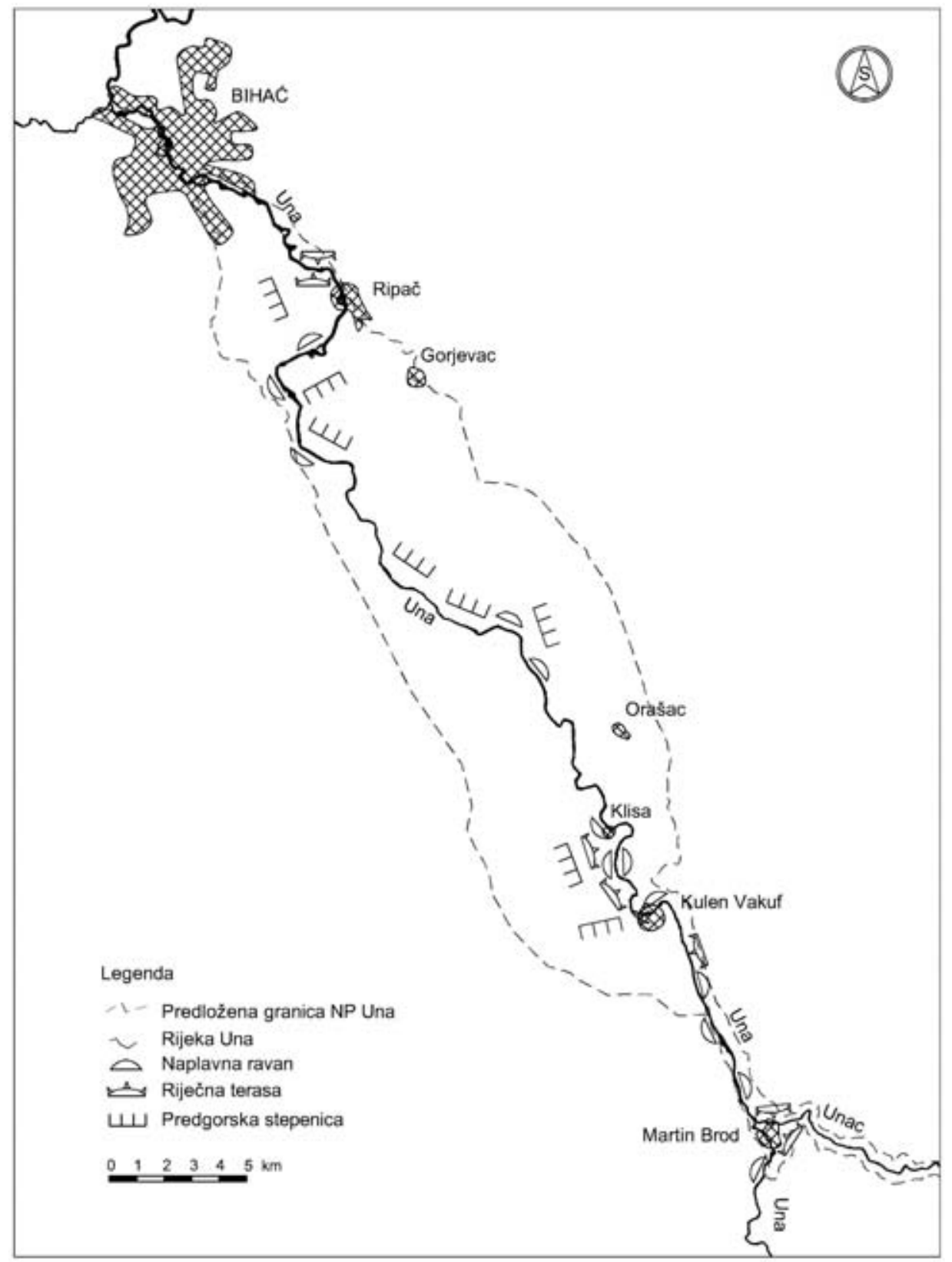

S1. 5. Karta vrednovanih reljefnih oblika oblika NP „Una“

Fig. 5 Map of the evaluated relief forms of the Una National Park 


\section{ZAŠTITA OKOLIŠA}

\section{Ugroženost osobitosti}

Rijeka Una kvalitetom svojih voda, pejsažno-ambijentalnim osobenostima riječnog korita i obala, raritetnim bogatstvom sedrenih naslaga, vodopadima, bukovima, brzacima, riječnim adama i ostalim prirodno - estetskim geomorfološkim, hidrološkim i biološkim sadržajima predstavlja zasada još nezagađen vodotok u svom gornjem poriječju (Grupa autora, 1980). Glavni dosadašnji zagađivači Une u ovome dijelu toka nisu u funkciji kao što su tvornica ljepka u Srbu (izvorišni dio) i tvornica celuloze u Drvaru, tako da je kvaliteta vode zadovoljavajuća. Aktualni problem može predstavljati prekomjerna sječa šume u gornjem poriječju Unca na padinama Klekovače, Šatora, Osječenice i Jadovnika što bi rezultiralo negativnim erozijsko-denudacijskim procesima koji bi se odrazili i na rijeku Unu. Treba napomenuti da je gornje poriječje Unca lepezastog ocrta što utječe na bujični karakter ove rijeke i pogoduje bržem razvoju destrukcijskih erozijskih procesa. Prekomjernom sječom i intenzivnom ispašom tijekom prošlog stoljeća devastiran je vegetacijski pokrivač dolinskih strana gornjeg toka Une (uzvodno od Martin Broda) i padina u poriječju njezinog desnog pritoka Krke. Danas su na tom području intenzivni procesi spiranja i jaruženja. Otpadne vode urbanih zona Drvara i Kulen Vakufa izlijevaju se direktno u ove rijeke. Navedeni štetni antropogeni utjecaji bi mogli negativno utjecati na kvalitetu voda, krška vrela (u dolini Unca), protoke, floru i faunu vodotoka što bi narušilo dinamiku razvoja izrazito osjetljivih sedrenih barijera u koritu Une. Odlaganje krutog otpada, uz ili u navedena riječna korita, još je jedna od postojećih negativnih pojava u ovome području. Izgradnja objekata na obalama Une koji svojim izgledom narušavaju pejsažno-ambijentalni sklad ili na sedrenim adama koje su izrazito osjetljive po svojim geomehaničkim značajkama su jedna od negativnih značajki koje treba spomenuti. Kontaminacija zemljišta minskoeksplozivnim sredstvima manjih dijelova ovoga područja predstavlja još jedan aktualan problem koji treba prioritetno rješiti.

\section{Prijedlozi mjera zaštite i monitoring-a}

Prvi najvažniji korak iz domene zaštite okoliša je usvajanje i provođenje zakonsko - pravne regulative kojom bi se gornje poriječje Une trajno zaštitilo kao nacionalni park. Zahvaljujući svojim bogatim prirodnim sadržajima (geomorfološko-hidrološki spomenici) i specifičnostima (unska sedra) ima predispozicije za povezivanje na europskoj razini sa Paneuropskom mrežom parkova. Shodno navedenom postoje mogućnosti upisa u Registar svjetske baštine UNESCO-a.

Perspektivni Nacionalni park "Una" bi pored širokih zona namijenjenih turizmu i rekreaciji imao i svoje strogo zaštićene zone - stroge rezervate prirode. Ovom prilikom predlažemo sljedeća područja koja treba strogo zaštiti :

\section{SPECIJALNI REZERVAT}

a) geomorfološko - hidrološki

- Kanjon Unca od Crnog vrela do Martin Broda

- Dolina Krke s vrelom Krke 


\section{SPECIJALNI REZERVAT}

b) ihtiološki

- Unac od Crnog vrela do sutoka sa Unom

- Dijelovi toka Une (kojeg stručno odrede ihtiolozi)

\section{SPOMENIK PRIRODE}

a) geomorfološko - hidrološki :

- riječno korito Une u Martin Brodu (vodopadi , bukovi, sedrene barijere )

- Štrbački buk

- Troslap

- Dvoslap

b) hidrološki:

- Vrelo Une

- Crno vrelo u klisuri Une

- Vrelo Ostrovice

c) geomorfološki:

- spilje u sedrenim naslagama - Martin Brod

Predlažu se sljedeće mjere zaštite područja budućeg nacionalnog parka:

- Obustavljanje prekomjerne sječe u gornjem poriječju Unca

- Pošumljavanje autohtonim vrstama padina izvorišnog dijela poriječja uzvodno od Martin Broda

- Izgradnja sustava za pročiščavanje otpadnih voda urbanih zona Drvara i Kulen Vakufa

- Korištenje prirodnih gnojiva pri poljoprivrednoj proizvodnji u gornjem poriječju Une

- Obustavljanje neplanske gradnje u budućem zaštićenom području

- Obaviti deminiranje kontaminiranog zemljišta

- Uspostaviti nove hidrometeorološke stanice

- Spriječiti krivolov kojim je posebno ugrožana ihtiofauna i divljač

- Uspostaviti stalnu službu u okviru nacionalnog parka koja će obavljati monitoring stanja kvalitete voda, zemljišta, šuma, biljnih i životinjskih zajednica. 


\section{ZAKLJUČAK}

Provedenim geoekološkim vrednovanjem reljefa istraživanog područja budućeg NP "Una" metodom indeksa rekreacijskog potencijala najvrijedniju 9. i 8. kategoriju imaju analizirani dostupniji reljefni oblici. Najizrazitije koncentracije oblika najvišeg stupnja vrijednosti prate rijeku Unu odnosno riječno korito Une i reljefne oblike u njegovoj blizini (sl. 4 i 5). Na temelju rezultata provedenoga geoekološkog vrednovanja reljefa možemo zaključiti da je rijeka Una prirodna okosnica ovoga perspektivnog zaštićenog područja.

Nakon cjelovito provedene geomorfološke analize i geoekološke evaluacije reljefa istraživanog područja smatramo da kompozitna dolina i tok Une treba predstavljati temeljnu odrednicu budućeg nacionalnog parka jer ima svoj prirodni kontinuitet. Zato predlažemo da se zaštićeno područje proširi na dolinu Krke, izvorišni dio doline s vrelom Une te lijevu dolinsku stranu od sutjeske nizvodno od Klise do Troslapa u Republici Hrvatskoj. Ovo područje obilježava bogatstvo kvalitetnih pitkih voda, resursa budućnosti, što je uz navedene geomorfološke značajke utjecalo da se opredjelimo za formiranje transnacionalnog parka "Una" - zaštićenog područja dvaju država BiH i Hrvatske. Ovo područje izuzetnih prirodnih ljepota zaslužuje epitet nacionalnog parka europskog značaja. Međusobno povezivanje s relativno bliskim Nacionalnim parkom "Plitvička jezera", također sedrotvornim područjem, bi u budućnosti moglo turistički afirmirati ovu regiju kao jedinstveno zaštićeno sedrotvorno područje Europe.

Vraćanjem u funkciju Unske pruge i aerodroma Željave kod Bihaća te poboljšanjem postojećih prometnica stvorili bi se realni uvjeti za masovniji posjet inozemnih turista i razvoja turizma u ovom zasad očuvanom području.

\section{POZIVNE BILJESKE}

1. Procjena udaljenosti (izražena u satima hoda) temelji se na vlastitom iskustvu.

2. "Recretion potential index (RP)". Metoda se temelji na računanju triju elemenata: P1 - topografski elementi (nagib padina, vertikalna raščlanjenost reljefa, broj vodenih površina /uključujući i more/), P2 - element šumskog pokrivača (sklop, visina stabala i udio šume "širokog lista") i P3 - dostupnost (nepristupačnost, nedostupnost, protezanje šumskih čestica). Na temelju tih pokazatelja indeks rekreacijskog potencijala računa se prema formuli:

$$
\mathrm{PR}=\mathrm{P} 1+\mathrm{P} 2+\mathrm{P} 3
$$

(Goodal and Whittow, 1973, preuzeto iz Mitchel, 1991, str. 353-354).

3. Metoda je prilagođena potrebama vrednovanja reljefa, pa su elementi šumskog pokrivača (P2) zamijenjeni pokazateljima estetske vrijednosti reljefa, a topografski elementi (P1) i dostupnost (P3) dopunjeni pokazateljima za fizičku dostupnost reljefa (za šetnju, planinarenja, alpinizam i kanjonstvo), odnosno, pokazateljima dostupnosti (već prema ranije definiranim zahtjevima vrednovanja reljefa za precizno definirane tipove rekreacija). (Saletto Janković, 1995.)

4. Vršni dio uzvišenja V. Ljutoč, padine Račića, Lohovskih brda i Debeljače kao i naplavne ravnice Kaluđerice i Račića su minirane te nisu geoekološki vrednovane. (Izvor: Karta minskih polja, 1:25000, BH MAC, Sarajevo, ožujak 2005.) 


\section{LITERATURA I IZVORI}

Bognar, A. (1987.): Reljef i geomorfološke osobine Jugoslavije, Veliki geografski atlas Jugoslavije, SNL, Zagreb

Bušatlija, I. (1976.): Geneza i morfologija kvartarnih naslaga u Bosni i Hercegovini, Geografski pregled br. 18-19, Sarajevo

Carter, N. (2004.): Strategije zaštite okoliša, Barbat, Zagreb

Fairbridge, R.W. (1968.): The Encyclopedia of Geomorphology, Reinhold Book Co., New York

Grupa autora (1960.): Vojno-inžinjerijski opis reke Une, Državni sekretarijat za poslove narodne odbrane, Beograd

Grupa autora (1985.): Uputstvo za izradu detaljne geomorfološke karte SFRJ u razmjeru 1:100 000, SANU, Beograd

Grupa autora (1983.): Daljinska istraživanja u geoznanostima, JAZU, Zagreb

Grupa autora, ( 1980.): Prirodne i kulturno -historijske vrijednosti BiH, Prostorni plan Bosne i hercegovine, Faza B -Valorizacija, Sarajevo

Grupa autora, (1986.): Nacionalni park Sutjeska - Prostorni plan posebnog područja, Urbanistički zavod Bih, Sarajevo (2005.): Karta minskih polja M 1: 25 000, BH MAC, Sarajevo

Katzer, F. (1901.): Zur Verbreitung der Trias in Bosnien, Wissensch. 21. Prag

Katzer,F. (1903.): Geologischer Furer durch Bosnien und die Herzegovina, Sarajevo

Matoničkin, I.; Pavletić, Z. (1963.): Sedrene naslage u rijeci Uni i njihova biološka uvjetovanost, Geografski glasnik br. 25, GDH, Zagreb

Miklos, L. (1994.): Spatial Organisation of the Landscape, Department of Geography and International Development Studies, Roskillde University, Roskillde

Milanović, P. (1979.): Hidrogeologija karsta i metode istraživanja, Institut za korištenje i zaštitu voda na kršu, Trebinje

Panjukov, P. N. (1965.): Injženjerska geologija, Građevinska knjiga, Beograd

Piha, B. (1973.): Prostorno planiranje, Beograd

Saletto, M. (1995.): Geoekološke osobine NP Paklenica, Doktorska disertacija, PMF- Geografski odjel, Zagreb

Spiridonov, A. I. (1975.): Geomorfologičeskoe kartografirovanie, Nedra, Moskva

Statistički ljetopis, (1999): Državni zavod za statistiku RH, 391. - 404. str., Zagreb

Taubman, I. (1980): Rekreacija u Bosni i Hercegovini, Instiut za arhitekturu, urbanizam i prostorno planiranje, Sarajevo

White, W. B. (1988.): Geomorphology and Hydrology of Karst Terrains, Oxford University Press, New York

Weber, V. (1950.): Kajak i kajakaštvo, Tehnička knjiga, Beograd

Zirić, M. (1987.): Vodič po rijekama Jugoslavije (za veslače i ribiče), Sportska tribina, Zagreb 


\title{
SUMMARY
}

\section{Geoecological Characteristics of the Upper Part of the Una River, From Martin Brod to Pritoka}

\begin{abstract}
Alen Lepirica
The upper Una River Valley, stretching from Martin Brod to Pritoka, is characterized by rich and appealing relief forms. Evaluation of the relief forms has been conducted by applying a geoecological method of indexing recreational potential for the purpose of tourism, sport, and recreation. The results indicate that the richest sections of the relief are located in or on the sides of the river bed. For the most part, the upper part of the Una River and its valley represent ecologically unpolluted areas. Due to the upper river valley's natural characteristics and unique environment, a legislative procedure has been initiated to declare the Una Valley National Park. After conducting in-depth geomorphological analyses, a geoecological evaluation, and a planning assessment, we have concluded that the upper river valley is an inseparable part of its spring valley. Consequently, we suggest that the area of the future Una National Park includes its spring area located in the Republic of Croatia. In that way the protected area will become known as a transnational park located in both Bosnia-Herzegovina and Croatia. Given the park's location, we envision that a future link between the Una National Park and Plitvice National Park will also create a unique and protected calcareous sinter region that will become a respectable tourist attraction, even for European standards.
\end{abstract}

Primljeno (Received): 1 - 02 - 2006.

Prihvaćeno (Accepted): 7 - 11 - 2006.

\section{Dr.sc. Alen Lepirica}

Samostalni stručni suradnik za geoznanosti Institutu za građevinarstvo

Kralja Petra Karađorđevića 92

78000 Banja Luka, Bosna i Hercegovina 